\title{
Social Gender Inequality in the Member, Candidate, Potential Canditate Transition Economies of the European Union and Turkey
}

\author{
Nuray GÖKÇEK KARACA (Corresponding author) \\ Anadolu University, Faculty of Health Sciences, Department of Social Work \\ 26470 Eskisehir, Turkey \\ E-mail: ngokcek@anadolu.edu.tr/nuraygokcek9@gmail.com
}

\begin{abstract}
Azmi Recep ÖZDAŞ
Anadolu University, Faculty of Health Sciences, Department of Social Work 26470 Eskisehir, Turkey
\end{abstract}

Received: July 3, 2015 Accepted: July 30, 2015 Published: August 20, 2015

doi:10.5296/jad.v1i1.8096 URL: http://dx.doi.org/10.5296/jad.v1i1.8096

\begin{abstract}
In this research, a comparative analysis of the gender inequalities between Turkey the member, candidate and potential candidate economies of the European Union is tried to be examined. To ensure equality and justice and to reach the level of the EU Member states in this regard, it is a necessity to reduce the gender inequality in society. Rather than comparing Turkey with all transition economies within the frame of the EU standards of gender inequality, it was decided to compare Turkey with the transition economies like itself that are EU Members, Member candidates and potential candidates. The Gender Inequality Index that was developed by the United Nations Development Program (UNDP) was used in the aforementioned comparisons. Research results show proof that there are unfavorable differences in Turkey in regards to the comparison of gender inequality with transition economies that are EU members, member candidates and potential candidates. This result shows that Turkey has omissions in all components of gender inequality, categorized as health care, participation in political life, access to education and participation in working life. Therefore Turkey needs to reconsider all these categories and their indicators.
\end{abstract}




\section{MInstitute ${ }^{\text {Mink }}$}

Keywords: Social Gender, Social Gender Inequality, Participation in Political Life, Participation in Working Life, Transition Economy

\section{Introduction}

Women have started to express their needs with the advent of developing feminist movement in the second half of the 19th Century and they have started to get organized and has acquired some rights in accordance with their needs. In this regard, one of the most iconic social and political struggle of the woman was to acquire the equal rights to elect and be elected. After the first and second World Wars, most women around the world have acquired rights to elect and be elected. This struggle, which began with the rights to elect and to be elected, continues in social, political, economic and cultural atmosphere. Despite the developments in human rights, democracy and equality, it is still impossible to say that all women around the globe benefit from the rights to elect and be elected. There are also a wide range of discriminations against women in all other fields.

Fields such as working life, education and benefiting from healthcare are among the ones where the women are discriminated against the most. One of the most important reasons for this is without a doubt, is the fact that there are socio-cultural obstacles, which keep the women from benefitting from the same employment opportunities and payments in the economy. Indeed, the traditional view that women work to support their families put female working force in the position of reserve workforce that is needed during the periods of economic development discarded during the periods of economic decline. Because of this, even when women have pretty much the same rights as men does, because of the view that it is the women's responsibility to raise children and do housework, they are either forced to double their labor or to withdraw from the labor market (Gökçek Karaca, 2013: 1). These unfavorable circumstances that the women and the girls face create the foundations of the gender inequality in the society. Gender inequality in society acts as a catalytic of inequalities within the other social relationships and it intersects with the other dimensions of the inequality in many ways. Therefore, gender inequality in society is the prerequisite for equality and justice in all fields of the social life.

To ensure equality and equity and to reach the level of the EU Member states in this regard, it is a necessity to reduce the gender inequality in society. Rather than comparing Turkey with all transition economies in regards to whether Turkey has reached the EU standards of gender inequality, it was decided to compare Turkey with the transition economies, like Turkey, that are EU Members, candidates and potential candidates. For this reason, purpose of this research is to compare Turkey with the member, candidate and potential candidate transition economies in European Union.

\section{Determining the Gender Inequality in Society}

Social gender is the "gender roles" that are created at different times and in different geographies by the roles and responsibilities that were imposed upon the men and women. Rather than just the biological differences between the man and woman, the social gender 


\section{Ml Macrothink}

emphasizes the social and cultural differences created by these biological differences (Dedeoğlu, 2000: 142; Demirbilek, 2007: 13; Karaca Çakınberk, 2011: 74-75).

The inequalities between the women and men that stem from the same sources in the work life, education and health fields can be explained better with the Gender Inequality Index (GII), which was developed with the same contexts as the Human Development Index (HDI) and the Inequality-adjusted Human Development Index (IHDI) (United Nations Development Program (UNDP), 2013).

GII reflects the social gender inequality based disadvantages into three dimensions and each of these dimensions consist of various indicators. The aforementioned dimensions are called GII Components and they can be categorized as the following (UNDP, 2013):

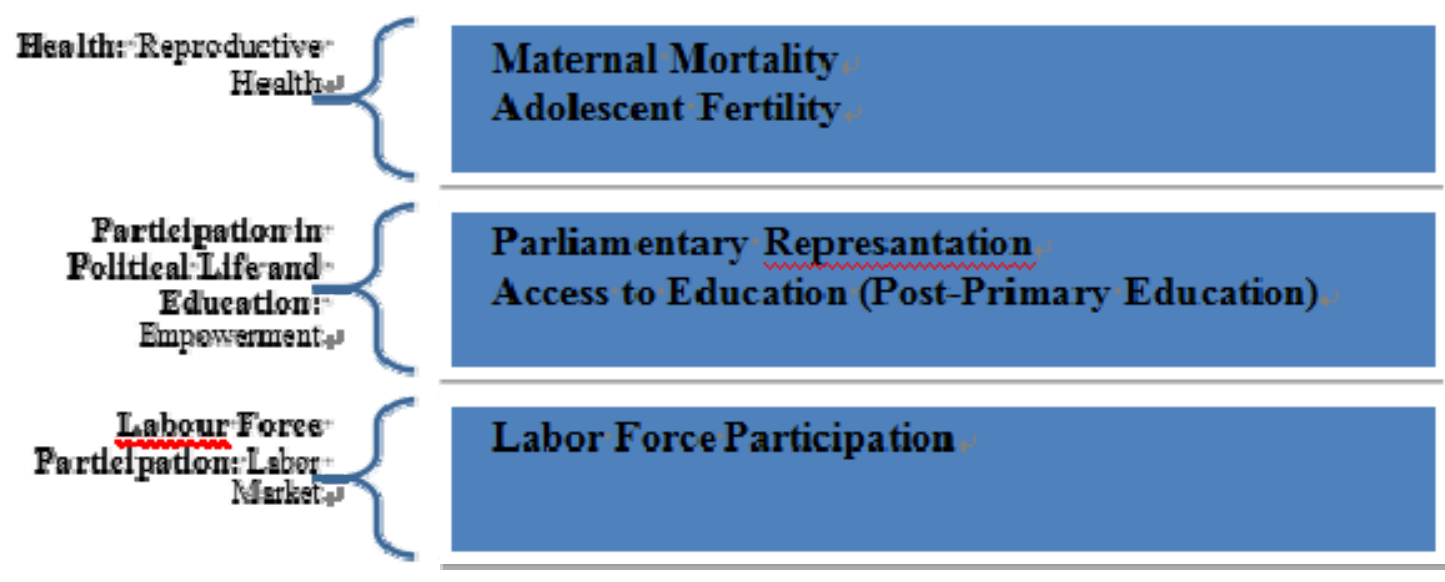

Figure 1. Dimensions of GII and Its Components

GII shows the potential human development losses on the bases of reproductive health, authority, and the discrepancy of gains between women and men. GII is valued between " $0-1$ ". Highest value GII can get is " 1 ", while the lowest is " 0 ". " 0 " is the point where the all measurable inequalities between social genders is the lowest; while at " 1 " the measurable inequalities are the highest. Therefore, closer this value is to " 0 ", the social gender inequality decreases, while closer to "1" means the inequality increases (UNDP, 2013).

With the dimensions of indicators that determine these dimensions mentioned above, the countries where the social gender inequalities are low have a value closer to " 0 " while the countries that have higher social gender inequalities have a value closer to " 1 ".

\section{The Dimensions of Social Gender Inequality in Turkey Member, Candidate and Potential Candidate Transition Economies of the European Union}

Social gender inequality is one of the most important components of human values and justice. Therefore, the social gender inequality must be considered within the frame of human values and along with the same values. In this context, the dimensions of the social gender inequality were scrutinized within the framework of human development in Turkey and 
member, candidate, potential candidate transition economies of the EU. The dimensions of social gender inequality were examined according to the components of GII within the aforementioned countries.

\subsection{Within Relation to Human Development}

While the social gender inequality appears to have a continuity independent of other inequalities due to social and historical processes, it cannot be said it manifested independent of country policies and social structures. Within this context, it is rational and consistent to evaluate the problem of social gender inequalities in Turkey and member, candidate and potential candidate transition economies of the EU with the HDI.

The dimensions of social gender inequalities in Turkey and the member, candidate and potential candidate transition economies of the EU are given in Table 1, which is an HDI and GII ranking made according to UNDP's Human Development Report (HDR) of 2014, created and based on the data gathered in 2013.

Table 1. The HDI and GII rankings according to the relationship between Social Gender Inequality and Human Development of Turkey and member, candidate and potential candidate transition economies of the EU

\begin{tabular}{|c|c|c|c|}
\hline \multirow{2}{*}{ Member Transition Economies of the EU } & \multirow{2}{*}{ HDI Rank } & \multicolumn{2}{|c|}{ GII } \\
\hline & & Rank & Value \\
\hline Bulgaria & 58 & 38 & 0.207 \\
\hline Czech Republic & 28 & 13 & 0.087 \\
\hline Estonia & 33 & 29 & 0.154 \\
\hline Croatia & 47 & 33 & 0.172 \\
\hline Hungary & 43 & 45 & 0.247 \\
\hline Latvia & 48 & 42 & 0.222 \\
\hline Lithuania & 35 & 21 & 0.116 \\
\hline Poland & 35 & 26 & 0.139 \\
\hline Romania & 54 & 54 & 0.320 \\
\hline Slovakia & 37 & 32 & 0.164 \\
\hline Slovenia & 25 & 1 & 0.021 \\
\hline \multicolumn{4}{|l|}{ Candidate Transition Economies of the EU } \\
\hline Albania & 95 & 44 & 0.245 \\
\hline Montenegro & 51 & ---- & ---- \\
\hline The former Yugoslav Republic of Macedonia & 84 & 31 & 0.162 \\
\hline Serbia & 77 & ---- & ----- \\
\hline \multicolumn{4}{|l|}{ Potential Candidate Transition Economies of the EU } \\
\hline Bosnia and Herzegovina & 86 & 36 & 0.201 \\
\hline Kosovo & ---- & ---- & ----- \\
\hline Turkey & 69 & 69 & 0.360 \\
\hline
\end{tabular}

Source: UNDP, 2014. 
As stated in the Human Development Report of 2014, the social gender inequality is in close relationship with the variables of human development, such as life expectancy at birth, expected schooling years, gross national product per capita (GDPPP), etc. As the results of the researches up to the states, if there is no equality in regards to human development in a country, there is no social gender inequality. In fact, it is observed that there are deep running inequalities between genders in these countries. Likewise, human development inequalities are observed in the countries without the social gender equalities (UNDP, 2013).

The result of the parallel between human development levels and social gender equality can be reached using data in the Table 1. The EU member transition economies are relatively higher ranked in regards to human development levels and have a more positive picture of social gender equality observed when compared to Turkey and the transition economies that are EU member candidates and potential candidates. According to Table 1, in regards to human development, Turkey $(\mathrm{HDI}=69, \mathrm{GII}=69)$ is in a better situation than all other member, candidate and potential candidate transition economies of the EU, except from Montenegro (HDI =51). Despite the expectancy, Turkey $(\mathrm{GII}=69)$ is in a worse condition than any other and member, candidate and potential candidate transition economies of the EU, when examined within the social gender equality frame.

\subsection{Within Relation to GII Components}

\subsubsection{Within Relation to Health}

Health is one of the most reflective field where social gender according to inequalities are observed. In this field, the social gender inequalities are observed mostly access of health care service basis. Mother deaths per 100.000 births and teenage pregnancy data based on births for every 1000 women between the ages of 15 and 19 are the two indicators in the healthcare field of the GII.

With the social gender inequalities in regard, indicators for the reproductive health in Turkey and member, candidate and potential candidate transition economies of the EU, which is one of the important components of GII, are given in Table 2.

Table 2 shows that no other member, candidate and potential candidate transition economies of the EU have lower mother death rates than Turkey, except from Romania, Hungary, Latvia and Albania. With the exception of Bulgaria and Romania, no other transition economies that are EU members, member candidates or potential candidates have a higher teenage pregnancy rate based on the women of ages between 15 and 19. Cultural values can explain the reason behind the negative picture that Turkey shows when it comes to teenage pregnancy rates, which shows a relatively positive picture when it comes to mother death rates. This is because of the fact that almost $14 \%$ of the married women in Turkey consist of girls aging between 10 and 14 (K1lıç, 2012). This fact moves the teenage pregnancy rate to the field of culture. The economic reflections of the cultural dimension of the teenage pregnancy problem should not be forgotten. In the second meeting of The Grand National Assembly of Turkey Commission for Woman - Man Opportunity Equality, dated 13/05/2009, it decided to research the reason behind early marriages and create solutions and to create the Sub 


\section{Macrothink}

Journal of Asian Development

ISSN 2377-9594 2015, Vol. 1, No. 1

Commission for The Research of Early Age Marriages (The Grand National Assembly of Turkey, 2010; Yüksel Kaptanoğlu and Ergöçmen, 2012). This can be evaluated as a development that supports the cultural dimension of the problem. Therefore, the fact that the cultural values are not used in the calculation in the GII component of teenage pregnancy rate calculations is an important deficiency. The biggest problem with the data in question is that it considers the healthcare field only from the aspect of reproduction. It is clear that for these problems to be eradicated, a new view that includes the social gender idea in itself, rather than a view that equates the female health with the reproductive health is a necessity (Turkish Medical Association, 2008). This because women are more susceptible to stress and sickness than men are. They are also under the health risks that may stem from early marriages, early pregnancies, sexually transmitted diseases, violence against women, mother or child deaths at birth, sexual harassment and sexual assault. Therefore, making a comprehensive argument on social gender based inequalities in the healthcare field is only possible with the data that also includes the aforementioned dimensions of the problem.

Table 2. Reproductive Health Indicators of 2014 in Turkey and Member, Candidate and Potential Candidate Transition Economies of the EU

\begin{tabular}{|c|c|c|}
\hline Member Transition Economies of the EU & $\begin{array}{l}\text { Maternal Mortality Ratio } \\
(2010)\end{array}$ & $\begin{array}{l}\text { Adolescent Birth Rate } \\
\quad(2010-2015)\end{array}$ \\
\hline Bulgaria & 11 & 35.9 \\
\hline Czech Republic & 5 & 4.9 \\
\hline Estonia & 2 & 16.8 \\
\hline Croatia & 17 & 12.7 \\
\hline Hungary & 21 & 12.1 \\
\hline Latvia & 34 & 13.5 \\
\hline Lithuania & 8 & 10.6 \\
\hline Poland & 5 & 12.2 \\
\hline Romania & 27 & 31.0 \\
\hline Slovakia & 6 & 15.9 \\
\hline Slovenia & 12 & 0.6 \\
\hline \multicolumn{3}{|l|}{ Candidate Transition Economies of the EU } \\
\hline Albania & 27 & 15.3 \\
\hline Montenegro & 8 & 15.2 \\
\hline The former Yugoslav Republic of Macedonia & 10 & 17.8 \\
\hline Serbia & 12 & 16.9 \\
\hline \multicolumn{3}{|c|}{ Potential Candidate Transition Economies of the EU } \\
\hline Bosnia and Herzegovina & 8 & 15.1 \\
\hline Kosovo & ----- & ----- \\
\hline Turkey & 20 & 30.9 \\
\hline
\end{tabular}

Source: UNDP, 2013. 
As with all fields of the social life, the inequalities in the healthcare field is not only in between the genders, but it can also manifest as intra gender problems when combined with various other factors. As the gender issue, especially concerning with woman, is multidimensional and has many specific, cultural-relative background, it is hard to have an exact statement up to the reports between men and women. On the other hand, hermeneutic approaches to gender issue can be much more useful in aspect to evaluate and uncover the hidden relations of gender problems; such as the relation between accessing to education and participation in political life or the public health and social status of women. It should be reconsidered that the potency of patriarchy can easily hide itself behind the excuses of normative social structural daily life. In a research done in 99 developing countries, there is a positive correlation between the fertility of a woman and their social status. The number of the children that a woman has decreases as her status rises. Likewise, higher social status means a better chance of taking advantage of the obstetric services. According to the Results of Advanced Analysis of the Research on Turkey's Population and Health, more educated women are more likely to receive prenatal care and to give birth in healthier conditions (Turkish Medical Association, 2008). Therefore, the inequalities not only stem from the social gender inequalities, it can also manifest as intra gender inequalities with the addition of different factors. In other words, while the Data provided by the UNDP will clearly prove to be beneficial for the approaches to the health policies and social gender inequality problems, it is clear that the data must be supported by other indicators.

\subsubsection{Within Relation to Participation in Political Life}

Women, like in many fields, have struggled for a long time to gain their rights in the political field. Despite the French Declaration of the Rights of Man and of the Citizen that declares the natural and unalienable rights such as freedom, rights to own property, safety and resisting oppression, for centuries, the rights of citizenship were exclusively for men. Women receiving citizenship rights akin to the ones that men possess were delayed because of the idea of citizenship was formed on the ground of an autonomous and rational individual, and the idea that woman are lacking in this regard. The women were only able to receive the rights to citizenship and election at late 19th and early 20th centuries (Öztürk, 2012). The primary indicator for GII's measurement for participation in political life is the representation rate in the national parliament. Representation rate of women in national parliaments of Turkey and the other member, candidate and potential candidate transition economies of the EU, which is a component of GII, is given in Table 3.

When the representation rate in national parliaments of the member, candidate and potential candidate transition economies of the EU are scrutinized; Turkey (14.2\%) falls behind of every EU member, candidate and potential candidate transition economy except from Hungary (8.8\%) and Romania (11.6\%). There is not much of a difference between EU member transition economies, Candidate transition economies and potential candidate transition economies. 
Table 3. The Representation in National Parliament in Turkey and the Other Member, Candidate and Potential Candidate Transition Economies of the EU by 2013

\begin{tabular}{lll}
\hline \multicolumn{1}{c}{ Member Transition Economies of the EU } & Share of Seats in Parliament \\
\hline Bulgaria & 24.6 \\
Czech Republic & 20.8 \\
Estonia & 23.8 \\
Croatia & 8.8 \\
Hungary & 23.0 \\
Latvia & 24.1 \\
Lithuania & 21.8 \\
Poland & 11.6 \\
Romania & 18.7 \\
Slovakia & 24.6 \\
Slovenia & 17.9 \\
\hline Candidate Transition Economies of the EU & 17.3 \\
Mlbania & 34.1 \\
The former Yugoslav Republic of Macedonia & 33.2 \\
Serbia & 19.3 \\
\hline Potential Candidate Transition Economies of the EU & ---- \\
Kosovo & 14.2 \\
\hline
\end{tabular}

Source: UNDP, 2013.

In Turkey, women have received rights to elect for local elections in 1930 and rights to elect for general elections in 1934. In the 1935 general elections, 18 female representatives were elected to the National Assembly, which means a 4.5\% representation in the parliament. The fact that in these years, many of the European, American or Asian countries did not have this right, makes this point very important (Gökçimen, 2008). While the participation of women in political life happened at a much earlier date compared to the rest of the world, the representation rate of women in The Grand National Assembly still remains low. Table 4 gives the rate of women's representation in the Grand National Assembly with regards to political parties.

Table 4. The Distribution of Representatives in the Grand National Assembly by Gender

\begin{tabular}{|c|c|c|c|c|c|}
\hline \multirow[b]{2}{*}{ Political Party Name } & \multicolumn{2}{|c|}{ Female } & \multicolumn{2}{|c|}{ Male } & \multirow[b]{2}{*}{ Party Total } \\
\hline & $\mathrm{N}$ & $\%$ & $\mathrm{~N}$ & $\%$ & \\
\hline Justice and Development Party & 34 & $\% 13,18$ & 224 & $\% 86,82$ & 258 \\
\hline Republican People's Party & 20 & $\% 15,14$ & 112 & $\% 84,85$ & 132 \\
\hline Peoples' Democratic Party & 31 & $\% 38,75$ & 49 & $\% 61,25$ & 80 \\
\hline Nationalist Movement Party & 4 & $\% 5,00$ & 76 & $\% 95,00$ & 80 \\
\hline & 89 & $\% 16,18$ & 461 & $\% 83,82$ & 550 \\
\hline
\end{tabular}

Source: The Grand National Assembly of Turkey, 2015. 


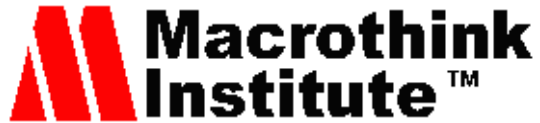

Table 4 shows that the Peoples' Democratic Party has a relatively high level of female representation, with the lowest being the Nationalist Movement Party, while the remaining parties having more or less the same amount of female representation. The local political fields show a clearer picture of the lack of female representation in the national politics. According to data retrieved from the General Directorate of Local Administrations, only $3.9 \%$ of the total electee's are women. The countries with the highest local women's representation are as follows: Sweden, Russian Federation, Republic Of Moldova, Belarus, Ukraine and Slovenia (Biricikoğlu, 2013).

While the quantitative aspect of the women's participation in political life is certainly important, the quality aspect is even more crucial. In this context, to what extent that women can produce quality based policies towards themselves and their levels of contribution to these policies is a question of extreme importance.

The importance of production of policies derives from the representation. Low participation rates prevent women to represent themselves in a rational procedure. Without the self-representation appearances, women are forced to be in a secondary position within the whole social dimensions mentioned above (education, health, participation in working life). This lack of representation causes a superficial production of policies. Policies implemented by men reproduce the unequal relations. Thus, a kind of vicious circle begins from the point of representation in political life.

Nevertheless, some updated civil society initiatives allow woman to open a new perspective in participation of political life. Even the recent elections held in last 5 years showed that the political parties have a tendency to manipulate public just by showing woman representatives as a tool of political advertisement, women based civil institutions and NGOs have a wide range of struggle to fight for woman quota before elections and after the election process to gain seats to be represented.

\subsubsection{Within Relation to Access to Education}

Education is a factor that comes up as a result of the social gender based inequalities and also as a catalyst for both inter and intra gender inequalities. This is because the education is an inequality factor as vital as how much it affects the levels of inequality in both the position of the women in the workforce market and the levels of benefit that they from health care services.

The ratio comparison of genders for people older than 25 and has received further education after primary school in Turkey and the other member, candidate and potential candidate transition economies of the EU is given in the Table 5. 
Table 5. Gender Population Comparison of People Older than 25 and Have Received Further Education Post-Primary School in Turkey and the Other Member, Candidate and Potential Candidate Transition Economies of the EU

\begin{tabular}{|c|c|c|}
\hline \multirow[t]{2}{*}{ Member Transition Economies of the EU } & \multicolumn{2}{|c|}{$\begin{array}{c}\text { Population with at least Some Secondary } \\
\text { Education, } 25+\end{array}$} \\
\hline & Female & Male \\
\hline Bulgaria & 93.0 & 95.7 \\
\hline Czech Republic & 99.9 & 99.7 \\
\hline Estonia & 100 & 100 \\
\hline Croatia & 85.0 & 93.6 \\
\hline Hungary & 97.9 & 98.7 \\
\hline Latvia & 98.9 & 99.0 \\
\hline Lithuania & 89.1 & 94.3 \\
\hline Poland & 79.4 & 85.5 \\
\hline Romania & 86.1 & 92.0 \\
\hline Slovakia & 99.1 & 99.5 \\
\hline Slovenia & 95.8 & 98.0 \\
\hline \multicolumn{3}{|l|}{ Candidate Transition Economies of the EU } \\
\hline Albania & 81.8 & 87.9 \\
\hline Montenegro & 84.2 & 94.7 \\
\hline The former Yugoslav Republic of Macedonia & 40.2 & 55.6 \\
\hline Serbia & 58.4 & 73.6 \\
\hline \multicolumn{3}{|l|}{ Potential Candidate Transition Economies of the EU } \\
\hline Bosnia and Herzegovina & 44.8 & 70.0 \\
\hline Kosovo & ----- & ----- \\
\hline Turkey & 39.0 & 60.0 \\
\hline
\end{tabular}

Source: UNDP, 2014.

When the ratio between women and men who access education after the primary school is examined, it is clear to see that among the member, candidate and potential candidate transition economies of the EU, Turkey has the lowest ratio (39.0\%). Likewise, Turkey is among the countries with lowest male education (60.0\%). This point may lead to the idea that the low levels of education in both women and men are caused by education policies and it is independent of the social gender inequality. But, Turkey is also among the countries where the difference of levels of education between women and men is the highest $(21.0 \%)$ Turkey is followed by Bosnia-Herzegovina (25.3\%), Macedonia (15.4\%) and Serbia (15.2\%) in regards to the inequality in accessing education. The only country where the women have a higher education rate than men is the Czech Republic with women having 99.9\% rate while men having $99.7 \%$.

Turkey is among the 24 countries that have the risk of not achieving the goal of UNESCO's Education for All 2015 program in regards to not ensuring the gender equality in primary and secondary education. Turkish Institution of Statistics' data also points towards a similar outcome. According to Turkish Institution of Statistics 2011 data, the rate of continuation of 
the 8-year compulsory primary education of female students $(98.56 \%)$ has progressed to the rate of male students (98.77). But in reality the number of women who don't know how to read and write is almost as 5 times as much of the number of men. Therefore, the inequalities in access to education in Turkey must be considered from both the angle of social gender inequality and the angle of general education policies.

Recent tendencies of national education policies show that the reformation of Turkish society basically restructured on education, especially primary education system. The transformation of new formal state's conservative approaches firstly rebound on education where the restriction against women begins. It can be explained by social background of country. But the two titles reinforce themselves. As the conservative regulations restricting girls' rights from primary steps, even with the accessing to education, women become more and more unwilling to participate in working life. They see themselves as the carrier of social formations by producing just at homes and dealing with households. Cultural contexts and political incentive policies confine women to a limited domestic environment. Therefore the link between recent social education policies and gender inequality should be evaluated together in a reciprocal aspect.

Table 6. Participation to Workforce and Gender in the Member, Candidate and Potential Candidate Transition Economies of the EU and Turkey

\begin{tabular}{llc}
\hline \multirow{2}{*}{ Member Transition Economies of the EU } & \multicolumn{2}{c}{ Labor Force Participation rate, 15+ } \\
\cline { 2 - 3 } Bulgaria & 47.8 & 58.8 \\
Czech Republic & 50.1 & 67.8 \\
Estonia & 56.0 & 68.7 \\
Croatia & 44.8 & 58.5 \\
Hungary & 44.7 & 59.9 \\
Latvia & 54.5 & 67.1 \\
Lithuania & 55.8 & 66.3 \\
Poland & 48.9 & 64.8 \\
Romania & 48.5 & 60.7 \\
Slovakia & 51.0 & 68.7 \\
Slovenia & 52.3 & 63.5 \\
\hline \multicolumn{1}{c}{ Candidate Transition Economies of the EU } & & 65.4 \\
Albania & 45.0 & ----- \\
Montenegro & ---- & 67.3 \\
The former Yugoslav Republic of Macedonia & 42.9 & ----- \\
Serbia & ----- & 50.8 \\
\hline \multicolumn{1}{c}{ Potential Candidate Transition Economies of the EU } & & 57.2 \\
Bosnia and Herzegovina & 34.1 & \\
Kosovo & ----- & \\
\hline & 29.4 & \\
\hline
\end{tabular}

Source: UNDP, 2014. 


\subsubsection{Within Relation to Participation in Work Life}

As shown by the GII, which is created by the UNDP, there are social gender inequalities in the fields of healthcare, education and participation in political life and there is also a difference in inequality levels between countries. Another extension to these differences and inequalities lies in the ratio of participation to the workforce. Table 6 presents the data regarding workforce participation of women and men older than 15 in transition economies and Turkey.

According to Table 6, the countries where the participation rates higher in the workforce are as the following: Estonia (56.0\%), Lithuania (55.8\%), Latvia (54.5\%), Slovenia (52.3\%) and Slovak Republic (51.0\%). The countries with the least women participating are as follows: Turkey, Bosnia-Herzegovina and Hungary. According to the Table 7, Turkey has the lowest rate of women participating in work force (29.4\%) while having the highest male participation (70.8\%). Turkey also has the greatest difference in the rates of participation of genders $(41.4 \%)$. Indeed, the difference in ratios of gender participation in the workforce is clearly increasing by the day. As Table 7 shows, the participation of women who are 15 and older in the workforce in the years between 2001 and 2005 were fluctuating between $49.3 \%$ and $51.2 \%$. This rate has dropped to $27.7 \%$ by the years between 2006 and 2008 .

Table 7. Employment Margins of Genders in Three Main Sectors by Years

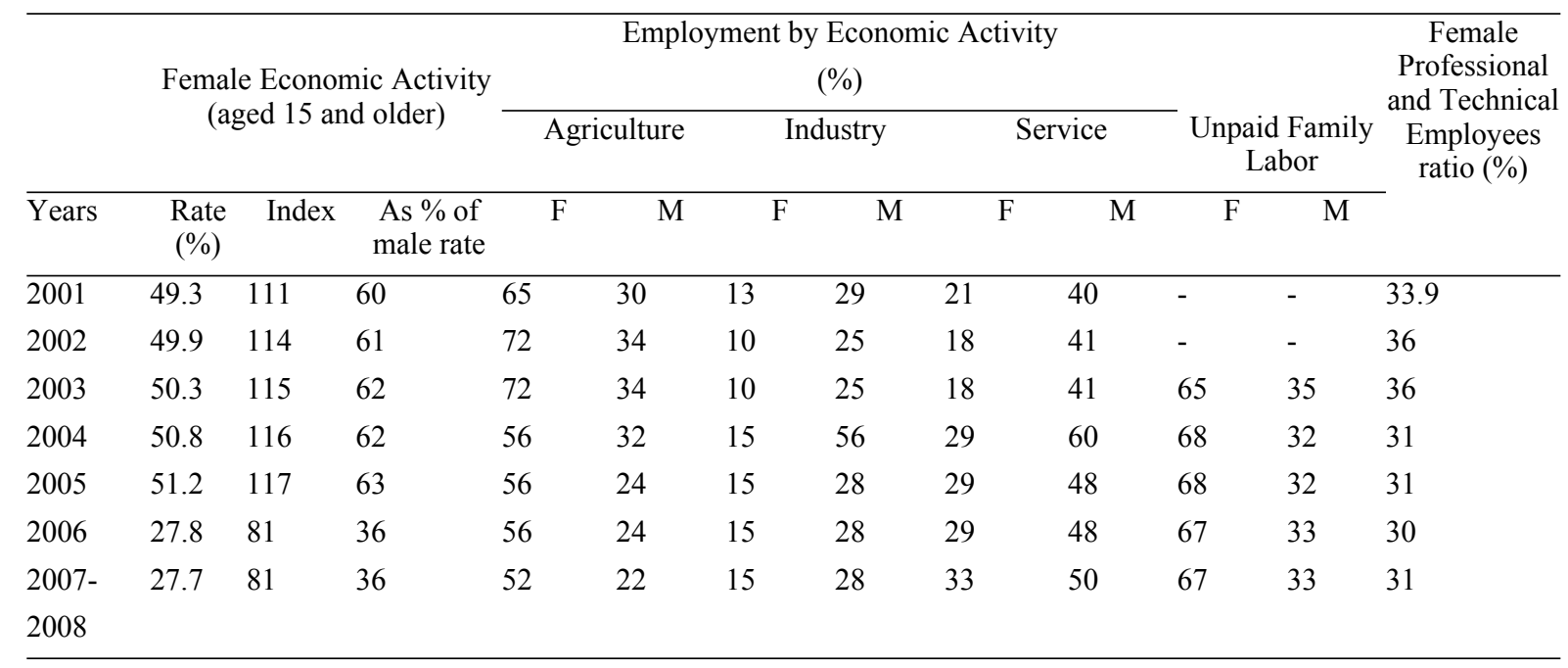

Source: UNDP, 2000-2008, Web: http: http://hdr.undp.org.

Despite the advances in the economy, urbanization and communication, the statistics show that the women are participating in the workforce less and less, and they remain in participation in short terms. In other words, the women either do not join the work life at all, or they leave it at the first opportunity. The reason behind this is the fact that most women in the workforce are employed in shadow sectors that do not have insurance, unionization, with low payments and unpredictable and very long work hours which means an overall worse working conditions compared to conditions that men have. Indeed, the process of immigration to cities from smaller settlements was accelerated by the fact that agriculture is 
losing its share in the gross domestic product. The newly immigrated women cannot benefit from the employment capacity of industry or service sectors and they are pushed to find employment in shadow sectors, lowering their participation in the overall workforce.

The women, who work as an unpaid family worker in the agriculture is not qualified, therefore they will either have unskilled labor or end up not participating in the workforce at all. In addition to this, when an educated woman enters the workforce market, she gains less income in comparison to men and has a limited chance to rise in the workplace. On the other hand, due to problems in the vocational education system, the vocationally educated women's workforce participation is hindered.

The fact that many women in Turkey work as unpaid family workers and with their unpaid invisible labor factoring in the calculation of total family income -like in many other countries- in Turkey, the woman's contribution to the total income appears to be higher than the man's. As a result, it can be said that the gender inequality is still very much persistent in regards to the economic activity ratio, generation of the index value and the factors that contribute to these calculations.

The low participation of women in the economic life is also effective in the formal sectors. This is because, the informal activities, where the women are more participant in the economic activity, are ignored in the calculations that determine the women's participation in economic activities. Because of this, as long as the informal economic activities are undocumented, the women's participation of economic life will always be lower. But the low amount of participation of women in the economic life cannot be explained only by the employment in informal sectors. The other reasons contributing to the matter should not be ignored. The legal regulations that were designed to protect female workers have led to employers who prefer male workers and to the opinion that women is the weaker gender that needs protection. This culminates in a way that women are inhibited from finding high paid grade employment, thus lowering the women's - especially the urban women's- contribution to the workforce. Another reason for low amounts of female workforce contribution is the fact that, despite the legal regulations and heavy sanctions, the women are still discriminated against and they have negative working conditions (Karadeniz-Y1lmaz, 2007: 35-40; T.C. Prime Ministers Directorate General on the Status of Women, 2008: 10; Gökçek Karaca, 2013).

The countries other than Turkey that have a discrepancy in the workforce participation based on social genders are as follows: Macedonia (28.3\%), Bosnia- Herzegovina $(23.1 \%)$ and Albania (20.4\%). But the high discrepancies in gender participation in workforce and the high rates observed in relation to the participation to workforce in Turkey and the other aforementioned countries is not a sufficient standard for measuring social gender inequality. This is because the data that presents the discrepancies and rates in question does not have the definition of the workforce market and it is gathered from the active population that is either seeking employment or in employment. This fact makes judging the position of genders in the workforce market difficult. Indeed, achieving high rates of workforce contribution can be achieved through work without insurance and/or employment in informal sectors. Also, 
the countries with younger populations can falsely appear to have a higher rate of workforce contribution because of the fact that the data is gathered from the active population that is either seeking employment or in employment.

With the economic development, types of employment that are fitting to the female labor demand are rapidly increasing in the labor markets. These types of employment usually don't require upper qualifications and they are fore mostly short termed or temporary employments. The course of economic development increases the undocumented employment types and the fact women are more preferred for these types of labors and the increase of women workforce demands to types of labors are all factors in the increase of the rate of the women's contribution to the overall workforce. The women's contribution to the undocumented employment is higher than men's contribution, especially because one-day works are more common in the female workforce. Due to economic crises, the desire to earn extra income for the family has motivated the uneducated women to find employment in informal sectors. One of the main reasons for the high rate of female employment in informal sectors is the fact that men see the female workforce as a cheap instrument to benefit. This social exclusion type of gender inequality forces the women to be alienated from social life and cannot participate in working life. Secondary acceptance of women position formulates a hierarchic relationship within the working life. Labour of women evaluated as an inferior type of participation. Thus makes the women labour cheap and easy to exploit. The abuse of woman labour derives from the potential perception of women status. It can be also evaluated as potential abuse through a linear inference. For example; while the domestic labour of woman ignored as a starting point, it bears a potential to be ignored in working life too. Women labour tendencies to service sectors and informal sectors can be explained via this conjecture.

- Women slow down or stop their career processes in order to raise their children.

- The prevalent perception concerning women is that they lack engineering, administration, and leadership skills.

- The quest by women to balance their roles in their family and business lives.

- Women's lack of the necessary business experience required for top level management.

- The perception that women lack the necessary authoritarian structure required for top level management due to their sensitive nature.

Therefore, an accurate evaluation of the contribution to the workforce can only be made with data on sectors and work types. Table 8 shows the margins of genders in three main sectors in the member, candidate and potential candidate transition economies of the EU and Turkey: 
Table 8. Margin of Genders in Three Main Sectors in The Member, Candidate And Potential Candidate Transition Economies Of The EU And Turkey

\begin{tabular}{|c|c|c|c|c|c|c|}
\hline \multirow{3}{*}{ Member Transition Economies of the EU } & \multicolumn{6}{|c|}{ Employment by Economic Activity (\%) } \\
\hline & \multicolumn{2}{|c|}{ Agriculture } & \multicolumn{2}{|c|}{ Industry } & \multicolumn{2}{|c|}{ Services } \\
\hline & Female & Male & Female & Male & Female & Male \\
\hline Bulgaria & 7 & 11 & 29 & 39 & 64 & 50 \\
\hline Czech Republic & 3 & 5 & 27 & 49 & 71 & 46 \\
\hline Estonia & 4 & 7 & 24 & 44 & 72 & 49 \\
\hline Croatia & 19 & 16 & 18 & 37 & 63 & 47 \\
\hline Hungary & 3 & 7 & 21 & 42 & 76 & 51 \\
\hline Latvia & 8 & 15 & 16 & 35 & 75 & 49 \\
\hline Lithuania & 11 & 17 & 21 & 37 & 68 & 46 \\
\hline Poland & 17 & 18 & 17 & 39 & 66 & 43 \\
\hline Romania & 33 & 31 & 25 & 35 & 42 & 34 \\
\hline Slovakia & 3 & 6 & 25 & 50 & 72 & 44 \\
\hline Slovenia & 9 & 9 & 25 & 47 & 65 & 43 \\
\hline \multicolumn{7}{|l|}{ Candidate Transition Economies of the EU } \\
\hline Albania & ----- & ----- & ----- & ----- & ----- & ----- \\
\hline Montenegro & ----- & ----- & ----- & ----- & ----- & ----- \\
\hline $\begin{array}{l}\text { The former Yugoslav Republic of } \\
\text { Macedonia }\end{array}$ & 19 & 20 & 30 & 34 & 51 & 46 \\
\hline Serbia & ----- & ----- & ----- & ----- & ----- & ----- \\
\hline \multicolumn{7}{|l|}{$\begin{array}{c}\text { Potential Candidate Transition Economies } \\
\text { of the EU }\end{array}$} \\
\hline Bosnia and Herzegovina & ----- & ----- & $\begin{array}{l}----- \\
\end{array}$ & ----- & $\begin{array}{l}---- \\
\end{array}$ & ----- \\
\hline Kosovo & ----- & ----- & ----- & ----- & ----- & ----- \\
\hline Turkey & 52 & 22 & 15 & 28 & 33 & 50 \\
\hline
\end{tabular}

Source: UNDP, 2013.

When the employment margin in three main sectors is scrutinized, it is shown that the women have the highest agricultural employment margin in Turkey (52\%). Turkey is followed by Romania, Croatia, and Macedonia. The transition economies that have the lowest female employment margins in agriculture are the Czech Republic, Slovak Republic and Hungary. Despite the high rate of female employment margin in the agriculture, Turkey is in the last place in regards to female employment margins in the industry $(15 \%)$ and services $(33 \%)$ among the member, candidate and potential candidate transition economies of the EU that have the highest female employment margins in the industry are Macedonia, Bulgaria and Czech Republic. Transition economies that have the lowest female employment margins in the industry are Latvia, Poland and Croatia. Transition Economies that have the highest female employment margins in the services are Macedonia, Latvia and Slovak Republic. Transition economies that have the lowest female employment margins in services are Romania, Croatia and Bulgaria. 
When the gender distribution of the sectors in Turkey is examined according to the data provided by the Table 8 , it is seen that the female employment in agriculture is almost as much as the industry and service employment numbers are combined. Conversely, transition economies that are EU members, candidates and potential candidates have services sectors that have a strikingly high rate of female employment margins. This proves that Turkey has a female employment numbers in agriculture beyond the comparison with the other member, candidate and potential candidate transition economies of the EU.

UNDP's sector oriented distribution values of the period between 2000 and 2008 show the inequalities that stem from properties and manners of female employment, albeit partially. For example, Estonia, the transition economy that has the highest rate of female workforce participating have a $4 \%$ of this workforce employed in the agricultural sector has $24 \%$ in the industrial sector and $72 \%$ in the services sector. In Turkey, the numbers are like the following: $52 \%$ in agriculture, $15 \%$ in industry and $33 \%$ services sectors. The $67 \%$ of this workforce is unpaid family workers while the $32 \%$ of it is professional and technical staff. In Estonia, the rate for unpaid family workers is $50 \%$, while the professional and technical staff rate is $70 \%$ (Gökçek Karaca, 2013). In Turkey, male worker margins are as following: 22\% in agriculture, $28 \%$ in industry and $50 \%$ in services. The rate for unpaid family work is $33 \%$. According to the GII data, Turkey, which has the highest rate of men participating in the labor markets, has most of its male workforce employed in the services sector. On the other hand, the female workforce is concentrated on the agriculture sector and unpaid family work.

The results given by the GII components show a great resemblance to the European Commission Development Reports, which states that the gender inequality in Turkey is an important problem. As a matter of fact, the European Commission Development Reports (2004-2013) state that the women in Turkey have low rates of employment, education and participation to the workforce. In fact, Turkey is in the last place when OECD countries are ranked by their rates of female participation to the workforce. And again, women are discriminated against in both the parliament and the workforce economy in Turkey. It is stated in the reports in question that, to adapt EU legislations, Turkey needs to solve the inequalities in economic and social aspects and needs to spend a lot of effort on improving the status of economic participation, education, opportunity equality and participation in politics. One common point of all reports is that the social gender inequality problems still persist despite all the previous reports. Indeed, the 2014 Development report of the Europe commission has pointed to the social gender inequalities in Turkey and it has stated that the problems emphasized in previous reports are still persistent (Europe Commission, 2014). Similarities of GII components and UNDP report results can be listed as following:

- Rate of representation in both local and general politics for women is low.

- Women aren't represented enough in jurisdiction and administrative echelons.

- Women are not included in the process of creating policies.

- The rates of women's participation in politics are low.

- Despite the increase of women's participation in workforce in comparison to the year of 2013, this rate still remains low. 
- Despite the low ratio of women who seek employment in regards to the general female population, female unemployment ratio is higher than male unemployment ratio.

- $1 / 3$ of employed women are working in agricultural sector as family employees.

- The unit of gender opportunity of equality that the EU Legal Acquis has prescribed, is still not established.

Like the EU development reports, the United Nations Women's Status Commission has stated in its 58th session that the development in regards to the one of their goals in the Millennium Development Goals called " the realization of social gender equality and empowerment of women" remain slow due to these reasons: "the persistent social gender inequality in secondary and higher education's in some districts, lack of economic empowerment, the exclusion of women from the formal economy, the lack of autonomy and independence of women, lack of equal access to full, productive and respectful employment, lack of representation in non-agricultural, paid employments, excess of representation in employment types such as domestic work or care work that are based on society's stereotypes, nonexistence of equal payment for equal jobs, unbalanced workload of unpaid care works and lack of actions on having care employees adapt, continuation discriminative behaviors, norms, stereotypes and legal frameworks, insufficiency of social protection and insurance for women, low and unequal participation and representation of women in national parliaments and other administrative structures, despite the whole progress. "(UNWSC, 2014).

\section{Conclusion}

The goal of this research is to make a comparative evaluation of social gender inequality, human development, rates of political representation, education and participation in the workforce between Turkey and the other member, candidate and potential candidate transition economies of the EU. This was based on the data provided by the Social Gender Inequality Index (GII) that was published in the Humane Development Report (2013).

It was deducted that countries that have higher levels of human development, also have lower values of social gender inequalities. The results of the research show that Turkey is excluded from this generalization. Despite Turkey's condition of being better developed in the matter of human development when compared to the other transition economies that are EU member candidates and potential candidates and encompassed in this gender equality comparison, Turkey falls behind on the levels of social gender equalities. In other words, the social gender inequalities are on higher levels when compared to the other countries in question.

In the health care field, Turkey falls behind of other transition economies that are EU members, member candidates and potential candidates when compared using the rate of teenage pregnancy. Turkey has a relatively more positive picture in regards to mother death rates. It is clear that the cultural angle of the matter of teenage pregnancies should be considered along with the healthcare field. The transition economies in question have varying rates in the healthcare field. These economies have more or less the same rate of representation in the national parliament with the exceptions of Hungary and Romania. Hungary remains at the bottom rank in the GII rankings of the political representation of 
women. In the matter of women's participation in political life, Turkey that established women's participation in political life earlier in comparison to many countries, still have low rates of female representation rate in the national assembly. In regards to the education after primary schools, Turkey has the lowest rates of education for both genders. But Turkey also has the highest rate of difference of education between the genders. Therefore, it can be said that the matter of education in Turkey has problems in both social gender and education policies. In the matter of participation in the workforce, the fact that the data is gathered from both employed and unemployed active populations means that the results would be meaningless. Instead, the importance was placed on sector distribution margins in the example of Turkey. According to this distribution, women are primarily employed in agriculture or as unpaid domestic workers, while the men are primarily employed in the services sector. In addition to this, when the transition economies and Turkey's position in the Gender Inequality Index is examined along with their position on the Human Development Index (HDI), the fact that human development levels that have a general parallel with the social gender equality becomes apparent.

It is clear that the data in question will help in the evaluation of social gender inequality and with the creation of new policies. But for a more comprehensive evaluation of the social gender inequality, more varied and qualified indicators are necessary. Otherwise, the current indicators have a risk of resulting in interpretations that are superficial and shallow. In addition to this, with regards to its own inner dynamics, when the position of social gender is considered independent of its other positioning in social life, another risk of superficiality arises. The reasoning behind this research's preference in using transition economies is to clear a way to consider this relationally with reference.

In regards to the statements that have been made, Turkey, as a country in the process of EU membership candidacy, needs to create policies that will decrease the teenage pregnancies, increase the levels of education, increase the representation in the national parliaments and will inhibit the concept of unpaid family worker. As long as Turkey doesn't create policies in this manner, the women's access to healthcare, politics, education and economic life will remain the same. Therefore, application of new policies -like the quota system-, as many advanced countries have, which will inspire and motivate women to take part in economic and political life must be actualized in Turkey.

Legal regulations for ensuring equality between men and women are not always effective in practice, and they often include elements which increase such inequality between the genders in Turkey, just as in the world in general. In fact, it can be seen that the policies and implementation for increasing the participation of women in management, educating them, improving their health, preventing all kinds of violence and abuse against them, improving their situation in the media, improving their economic status, and increasing their participation in economic life, are often not based on gender analysis. Therefore, being able to obtain efficient results from the subject policies and programs towards ensuring equality between men and women requires their preparation and implementation within a gender based perspective and with integrity tied to comprehensive and clear objectives. In addition, it should not be forgotten that the subject policies and programs must be supported by an 
education policy that questions the traditional roles of men and women and ensures change. Finally, it must be emphasized that equality policies could enter the social agenda of Turkey and occupy an important place in this agenda through the efforts and solidarity of women themselves.

\section{References}

Biricikoğlu, H. (2013). Failure of the Women's Representation in Local Government: A Survey Conducted in Sakarya. Sakarya Journal of Economics, 2(7), 1-31.

Çabuk Kaya, N. (2013). Gender equality and education in Turkey. Retrieved April 21, 2014, from http://kizlarinegitimi.meb.gov.tr/files/img/toplum_cinsiyet_ve_egitim.pdf

Dedeoğlu, S. (2009). Is Equality Is Discrimination? Welfare State in Turkey, Gender Equality Policies and Women's Employment. Labor and Social, 2, 41-54.

Demirbilek, S. (2007). Investigation in Terms of Sociological of Gender Discrimination, Finance Political \& Economic Comments, 44(511), 12-27.

European Commission. (2014). Turkey progress report 2014. Retrieved February 2, 2015, from http://www.ab.gov.tr/files/ilerlemeRaporlariTR/2014_ilerleme_raporu_tr.pdf

Gökçek Karaca, N. (2013). The Position of Women in Economics Life: A Comparison Between the Transition Economics and Turkey, International Conference on Eurasian Economies 2013, 428-434, Retrieved May 12, 2014, from http://www.eecon.info/papers/638.pdf

Gökçimen, S. (2008). Political Life Participation Challenge of Women in Our Country, Legislative Journal, 10, 5-59. Retrieved March 12, 2014, from http://www.yasader.org/web/yasama_dergisi/2008/sayi10/Ukemizde_Kadinlarin_Siyasi_Hay ata.pdf

Karaca Çakınberk, A. (2011). Being a woman in job, İstanbul: Nobel academic publishing.

Karadeniz, O., \& Y1lmaz, H., 2007. The position of women within the workforce market in turkey and the factors that influence their participation in the workforce market. Woman in business world. Istanbul: TURKONFED, 23-42.

Kılıç, A. (2012). Issue of Child Brides, Journal of Education, 33. Retrieved August 25, 2014, from http://www.egitisim.gen.tr/site/arsiv/73-33/664-cocuk-gelin-sorunu.html

Öztürk, Z. A. (2012). Women in the International Politics and Decision Making Process, ESAM Journal, 3 (1), 85-106. Retrieved August 25, 2014, from http://esam.ege.edu.tr/makaleler/ocak-2012/makale-1.pdf

The Grand National Assembly of Turkey (2010). Distribution of The Grand National Assembly of Turkey members of parliament by Gender. Retrieved June 27, 2015, from https://www.tbmm.gov.tr/develop/owa/milletvekillerimiz_sd.dagilim 


\section{Macrothink}

The Grand National Assembly of Turkey (2010). Reports on investigation about early marriages. $\quad$ Retrieved November $27, \quad 2014, \quad$ from http://www.tbmm.gov.tr/komisyon/kefe/docs/komisyon_rapor.pdf

Turkish Medical Association (2008). Gender in Turkey, woman and health. Retrieved November 27, 2014, from http://www.ttb.org.tr/en/index.php/tuem-haberler-blog/44-yeni-raporlar/945-qtuerkiyede-topl umsal-cinsiyet-kadn-ve-salkq-rapor

T. C. Prime Ministers Directorate General on the Status of Women (2008). Position of woman in turkey. Ankara.

UNWSC (2014). Challenges and achievements in the implementation of the millennium development goals for women and girls, commission on the status of women, Fifty-eighth session, 10-21. Retrieved February 2, 2014, from http://www.unwomen.org/ /media/Headquarters/Attachments/Sections/CSW/58/CSW58-agr eedconclusions-advanceduneditedversion.pdf

UNDP, Human development report, 2000, 326-329. Retrieved May 5, 2009, from http://hdr.undp.org/en/media/HDR_2000_EN.pdf

UNDP, Human development report, 2001, 326-329. Retrieved May 5, 2009, from http://hdr.undp.org/en/media/completenew1.pdf).

UNDP, Human development report, 2002, 326-329. Retrieved May 5, 2009, from http://hdr.undp.org/en/media/HDR_2002_EN_Complete.pdf

UNDP, Human development report, 2003, 326-329. Retrieved May 5, 2009, from http://hdr.undp.org/en/media/hdr03_complete.pdf

UNDP, Human development report, 2004, 326-329. Retrieved May 5, 2009, from http://hdr.undp.org/en/media/hdr04_complete.pdf

UNDP, Human development report, 2005, 326-329. Retrieved May 5, 2009, from http://hdr.undp.org/en/media/HDR05_complete.pdf

UNDP, Human development report, 2006, 326-329. Retrieved May 5, 2009, from http://hdr.undp.org/en/media/HDR06-complete.pdf

UNDP, Human development report, 2007-2008, 326-329. Retrieved May 5, 2009, from http://hdr.undp.org/en/media/HDR_20072008_EN_Complete.pdf

UNDP. (2013). Human development report, 2013, 156-160. Retrieved May 6, 2014, from http://hdr.undp.org/en/statistics/gii/

UNDP. (2014). Human development report, 2013. Retrieved July 10, 2014, from http://hdr.undp.org/sites/default/files/reports/14/hdr2013_en_complete.pdf

Yüksek Kaptanoğlu, İ., \& Ergöçmen, B. A. (2012). The road to being a child bride. Sociology Research Journal, 15(2), 128-161. 


\section{Copyright Disclaimer}

Copyright reserved by the authors.

This article is an open-access article distributed under the terms and conditions of the Creative Commons Attribution license (http://creativecommons.org/licenses/by/3.0/). 